\title{
PEMANFAATAN TEKNOLOGI UAV (UNMANNED AERIAL VEHICLE) UNTUK IDENTIFIKASI DAN KLASIFIKASI JENIS - JENIS KERUSAKAN JALAN
}

\author{
Iradaf Mandaya $^{1 *}$, Harintaka $^{2}$ \\ ${ }^{1}$ Mahasiswa, Magister Teknik Geomatika, Departemen Teknik Geodesi, FT-UGM \\ ${ }^{2}$ Dosen, Departemen Teknik Geodesi, FT-UGM \\ *Korespondensi: iradaf.mandaya@yahoo.co.id
}

\begin{abstract}
Road maintenance, repair, and rehabilitation are important parts of road infrastructure. Before that steps are needed to identify each type of road distress. UAV (Unmanned Aerial Vehicle) is a platform that has advantages to produce a geographical database. The location of this research is Jembangan road which is in Tulung District, Klaten Regency. The road structure was studied in flexible pavement. Aerial photo data is processed and analyzed by using SfM software to produce orthophoto. orthophoto is used in the process of visual interpretation to identify road distress. The results were obtained by several types of road distress in the form of alligator cracking, potholes, edge cracking, shoving, and depression. This type of road distress classification was obtained an accuracy rate of $96.36 \%$.
\end{abstract}

Keywords: aerial photo, road distress, structure from motion, orthophoto, visual interpretation.

\section{PENDAHULUAN}

\subsection{Latar Belakang}

Jalan adalah infrastruktur transportasi yang menyediakan aksesibilitas untuk mendukung pertumbuhan ekonomi dan kegiatan sosial. Jalan memainkan peran penting sejalan dengan perkembangan moda transportasi yang semakin maju dan cepat serta meningkatkan kegiatan ekonomi [1].

Jalan adalah prasarana transportasi darat yang meliputi segala bagian jalan, termasuk bangunan pelengkap dan perlengkapannya yang diperuntukkan bagi lalu lintas, yang berada pada permukaan tanah, di atas permukaan tanah, di bawah permukaan tanah dan/atau air, serta di atas permukaan air, kecuali jalan kereta api, jalan lori, dan jalan kabel (Undang-Undang Republik Indonesia No.38/2004 tentang Jalan). Infrastruktur Jalan yang baik merupakan prasarana penting dalam transportasi untuk dapat menunjang aktivitas perekonomian, pendidikan, sosial, budaya maupun politik di suatu wilayah.

Demi menciptakan kenyamanan dan keamanan bagi pengemudi, jalan harus didukung oleh perkerasan yang baik.
Perkerasan jalan adalah campuran antara agregat dan bahan ikat yang digunakan untuk melayani beban lalu lintas. Perkerasan jalan dibagi atas dua kategori yaitu perkerasan lentur (flexible pavement) dan perkerasan kaku (rigid pavement). Perkerasan lentur adalah perkerasan yang menggunakan aspal sebagai bahan pengikat sedangkan perkerasan kaku adalah jenis perkerasan jalan yang menggunakan beton sebagai bahan utama perkerasan tersebut [2].

Umur jalan yang sudah direncanakan pada kenyataannya tidak sesuai dengan realitas yang terjadi. Seringkali jalan mengalami kerusakan sebelum masa layanannya selesai. Faktor faktor seperti suhu, kelembaban, cuaca, dan beban lalu lintas kendaraan dapat mempengaruhi struktur perkerasan lentur dan menghasilkan berbagai tekanan yang menyebabkan kerusakan pada permukaan jalan, yang tidak hanya memengaruhi penggunaan jalan raya, tetapi juga menyebabkan kerugian ekonomi [3]. Oleh karena itu, mengidentifikasi kerusakan perkerasan jalan sangat penting untuk pemantauan kondisi jalan, pemeliharaan jalan, 
dan manajemen pada suatu ruas jalan [4][5].

Data kerusakan perkerasan dapat dikumpulkan dengan berbagai cara. Salah satu metode survei yang tergolong paling lama untuk mengumpulkan informasi kerusakan perkerasan adalah dengan berjalan di sepanjang jalan dan mengukur parameter yang diperlukan melalui inspeksi manual. Di masa lalu, penentuan dan evaluasi kerusakan perkerasan umumnya dilakukan dengan "manual inspections" atau "walk and look measurements". Dalam prosedur ini, seorang surveyor berjalan di sepanjang jalan dan mengumpulkan data visual dan kuantitatif dari permukaan jalan dengan menyelidiki setiap kerusakan [6].

Karena metode ini memakan waktu, maka metode pengumpulan data kerusakan permukaan jalan terus dikembangkan seiring dengan perkembangan teknologi. Penggunaan UAV (Unmanned Aerial Vehicle) yang digunakan dalam bidang pemetaan melonjak dalam beberapa tahun terakhir. UAV hadir dalam berbagai bentuk dan ukuran yang dapat terbang membawa sensor kamera untuk keperluan pemotretan udara yang dapat digunakan dalam berbagai aplikasi. UAV memberikan daya tarik bagi para pengguna yang dapat melakukan penelitian dengan cara yang jauh lebih fleksibel [7].

UAV adalah platform yang dapat menghasilkan data spasial 2D (dua dimensi) maupun 3D (tiga dimensi) yang memiliki referensi geografis dan resolusi spasial yang tinggi. Teknologi ini juga dapat digunakan untuk membantu surveyor dalam kegiatan identifikasi, dokumentasi, analisis serta menilai tingkat kerusakan lapisan permukaan jalan sehingga dapat dirumuskan langkah-langkah yang tepat dalam upaya mengatasi masalah manajemen infrastruktur jalan.

Dalam perkembangannya, UAV telah dimanfaatkan dalam bidang transportasi, salah satunya dalam pengukuran simpang jalan untuk keperluan perencanaan lalu lintas [8]. Pemanfaatan UAV dapat dieksplorasi lebih jauh tidak hanya bidang lalu lintas tetapi juga manajemen sarana transportasi jalan. Berdasarkan hal tersebut, dalam penelitian ini dilakukan eksplorasi kemampuan foto udara yang dipotret menggunakan wahana UAV untuk akuisisi data kerusakan jalan.

\section{LANDASAN TEORI}

\subsection{Tinjauan Pustaka}

Pemanfaatan UAV dalam berbagai bidang telah mengalami perkembangan yang cukup pesat dalam kurun waktu 5 tahun terakhir. Dibidang kehutanan, UAV dengan kamera multispectral dapat digunakan sebagai salah satu platform untuk mendeteksi dan memantau gejala wabah penyakit pada vegetasi melalui simulasi yang menghasilkan perubahan warna pada daun dengan resolusi spasial citra 6 $\mathrm{cm}$. Penelitian yang dilakukan oleh [9] menunjukkan bahwa UAV dengan kamera MicaSense dapat digunakan untuk menghitung estimasi spectral indices seperti NDVI (Normalized Difference Vegetation Index) yang memiliki peran penting dalam pengawasan kesehatan vegetasi dari berbagai aspek khususnya spasial dan temporal.

UAV juga dapat digunakan untuk mengidentifikasi dampak bencana tanah longsor serta melihat perubahan suatu daerah sebelum dan setelah terjadi bencana. [10] melakukan studi yang melibatkan analisis perubahan, pengukuran volumetrik dan topografi, analisis geomorfologi pada bencana tanah longsor yang terjadi di Okeanos, Yunani. Selain identifikasi pasca bencana, pemanfaatan UAV juga dapat digunakan untuk pemantauan dan evaluasi kerusakan pasca bencana alam, perencanaan distribusi logistik saat bencana alam maupun penilaian kerusakan infrastruktur pasca bencana alam [11].

Dalam bidang transportasi, survey kondisi permukaan jalan adalah salah satu aspek penting sebelum menentukan strategi pemeliharaan jalan. Metode survei yang paling sederhana adalah dengan melakukan inspeksi terhadap kondisi jalan yang dilakukan secara visual. Survei ini memerlukan biaya yang tinggi serta memakan waktu sehingga untuk mengatasi keterbatasan proses evaluasi secara visual, beberapa upaya dilakukan untuk mengembangkan perangkat teknologi dalam akuisisi dan deteksi kerusakan permukaan jalan [12].

Penelitian yang dilakukan oleh [13] menemukan bahwa data kerusakan jalan dapat dikumpulkan melalui rekaman video menggunakan kamera yang dipasang pada mobil. Elevasi permukaan yang direkam dari akselerometer pada mobil diproses untuk merekonstruksi profil melintang serta kedalaman lubang pada jalan. Perangkat GPS 
(Global Positioning System) disinkronkan dengan sensor lain untuk memperoleh geolokasi data. Kerusakan yang terdeteksi kemudian diklasifikasikan menurut jenisnya dan tingkat kerusakannya. Selain kerusakan jalan, penggunaan video frame juga dapat digunakan untuk mendeteksi tambalan jalan dengan metode kernel tracker [14]. Ketika tambalan terdeteksi, kotak pembatasnya diteruskan ke tracker, yang kemudian melacak tambalan tersebut dalam frame berikutnya. Tingkat akurasi deteksi diperoleh dengan cara membandingkan hasil metode kernel tracker dengan hasil identifikasi secara manual memiliki akurasi deteksi $75 \%$.

Penelitian ini menggunakan data foto udara yang diolah dengan metode SfM (Structure from Motion) untuk menghasilkan citra orthophoto dari serangkaian foto udara yang bertampalan. Mosaik ortophoto tersebut selanjutnya digunakan untuk identifikasi dan klasifikasi jenis-jenis kerusakan jalan.

\subsection{Jenis Jenis Kerusakan Jalan}

Beberapa Jenis kerusakan jalan berdasarkan Manual pemeliharaan jalan Direktorat Jenderal Bina Marga No.3/MN/B/1983 kerusakan jalan dapat dibedakan sebagai berkut:

1. Retak kulit buaya (alligator cracking) yakni retak kulit buaya adalah serangkaian retak memanjang paralel yang membentuk banyak sisi menyerupai kulit buaya.

2. Retak pinggir (edge cracking), retak memanjang jalan dengan atau tanpa cabang yang mengarah ke bahu jalan dan terletak dekat bahu. Retak ini disebabkan oleh tidak baiknya sosokan dari arah samping, drainase kurang baik, terjadi penyusutan tanah, atau terjadi settlement di bawah daerah tersebut.

3. Sungkur (shoving) adalah jenis kerusakan jalan yang ditandai dengan perpindahan lapisan perkerasan pada bagian tertentu yang disebabkan oleh beban lalu lintas yang mendorong berlawanan dengan perkerasan dan akan menghasilkan pola kerusakan seperti ombak pada lapisan perkerasan.

4. Lubang (potholes) berbentuk seperti mangkuk mirip dengan yang ada di jalan yang tidak beraspal, biasanya terbentuk sebagai akibat dari retakan yang tidak dirawat. Lubang diakibatkan oleh hilangnya lapisan aus dan material lapis pondasi.

5. Amblas (depression) merupakan kerusakan jalan yang terjadi dengan atau tanpa retak yang disebabkan beban kendaraan yang melebihi perencanaan, pelaksanaan yang kurang baik, atau penurunan bagian perkerasan dikarenakan tanah dasar mengalami settlement.

6. Tambalan (Patch) adalah salah satu jenis kerusakan jalan berupa tambalan bekas kerusakan pada periode perkerasan sebelumnya.

Gambar 1 di bawah merupakan beberapa jenis kerusakan jalan yang diklasifikasi menurut Bina Marga.

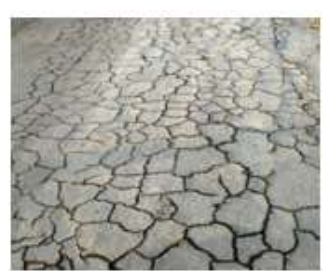

(a)

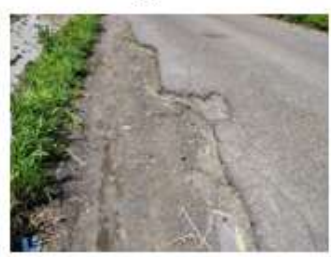

(c)

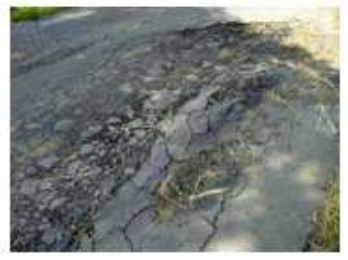

(e)

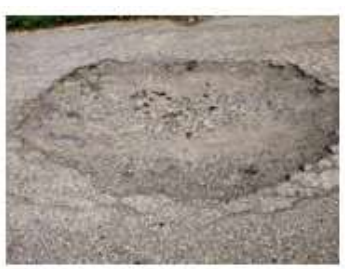

(b)

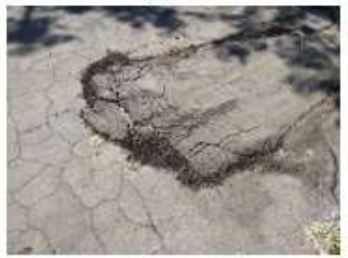

(d)

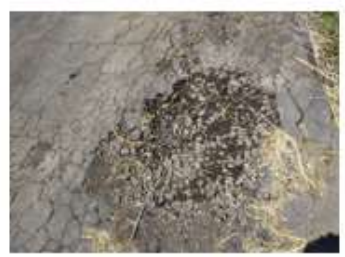

(f)
Gambar 1. Jenis-jenis kerusakan jalan. (a) retak kulit buaya, (b) lubang, (c) retak tepi, (d) tambalan, (e) sungkur, (f) amblas

(sumber: dokumentasi lapangan)

\subsection{Pengolahan Data Foto Udara Secara Fotogrametri}

Fotogrametri merupakan salah satu pengukuran dan interpretasi dari citra untuk memperoleh informasi (luas, area, volume dan koordinat) lokasi suatu objek dengan menggunakan lebih dari satu buah foto. Tujuan utama dari pengukuran secara fotogrametris 
adalah rekonstruksi tiga dimensi suatu objek atau untuk keperluan produksi peta [15]. Pemrosesan data fotogrametri telah mengalami perkembangan yang cukup pesat dari metode analitik hingga era computer vision. Computer vision memperkenalkan metode Structure from Motion (SfM) dalam pengolahan data foto udara untuk menghasilkan DSM/DTM dan ortofoto.

Pada prinsipnya SfM menggunakan lebih dari satu gambar stereo untuk merekonstruksi geometri objek (structure) berdasarkan perhitungan parameter orientasi yakni IO (Interior Orientation, atau parameter kalibrasi kamera) dan EOP (Exterior Orientation Parameter, yaitu posisi dan orientasi) saat kamera melakukan pemotretan foto sehingga menghasilkan data yang bersifat tiga dimensi yang dapat terlihat dari berbagai posisi [16].

Dalam menentukan EOP satu blok foto udara, dilakukan dengan bundle adjustment dengan dasar persamaan kolinearitas. Kolinearitas adalah kondisi yang menyatakan bahwa lokasi suatu objek di atas permukaan tanah, pada foto, dan posisi titik pusat kamera berada dalam satu garis lurus. Persamaan kolinear adalah sebagai berikut:

$x_{a}=x_{0}-f\left[\frac{r_{11}\left(X_{A}-X_{L}\right)+r_{21}\left(Y_{A}-Y_{L}\right)+r_{21}\left(Z_{A}-Z_{L}\right)}{r_{13}\left(X_{A}-X_{L}\right)+r_{23}\left(Y_{A}-Y_{L}\right)+r_{23}\left(Z_{A}-Z_{L}\right)}\right]$

(1a)

$y_{\alpha}=y_{0}-f\left[\frac{\left[r_{12}\left(X_{A}-X_{L}\right)+r_{22}\left(Y_{A}-Y_{L}\right)+r_{32}\left(Z_{A}-Z_{L}\right)\right.}{r_{13}\left(X_{A}-X_{L}\right)+r_{23}\left(Y_{A}-Y_{L}\right)+r_{33}\left(Z_{A}-Z_{L}\right)}\right]$

Keterangan:

$\mathrm{X}_{\mathrm{L}}, \mathrm{Y}_{\mathrm{L}}, \mathrm{Z}_{\mathrm{L}}$ : pusat proyeksi kamera saat eksposure

$X_{A}, Y_{A}, Z_{A} \quad$ : Adalah titik koordinat objek pada ground

$\mathrm{x}_{\mathrm{a}}, \mathrm{y}_{\mathrm{a}} \quad$ : sistem koodinat foto

$f \quad$ : panjang focal length kamera

$\mathrm{x}_{0}, \mathrm{y}_{0} \quad$ : offset titik pusat foto

$\mathrm{r} \quad$ : matrik rotasi, fungsi dari omega, phi dan kappa

\subsubsection{Pemrosesan data dengan Structure from Motion (SfM)}

Tahapan pengolahan data foto dengan metode Structure from Motion hingga menghasilkan produk ortophoto adalah sebagai berikut:

\section{Align photo}

Tahap ini merupakan tahap identifikasi obyek yang sama yang terdapat dalam foto stereo atau beberapa foto. Tahap ini dilanjut dengan menghitung posisi dan orientasi setiap foto dan dilanjutkan menghitung sparse point cloud. Hasil ini masih berupa DSM yang belum rapat.

\section{Build Dense Cloud}

Pada tahap ini dilakukan perapatan point cloud yang telah dihasilkan pada tahapan sebelumnya. Model point cloud yang telah rapat dan detail ini jika divisualisakan akan nampak hampir seperti kondisi di lapangan yang sebenarnya.

\section{Mesh}

Mesh merupakan tahapan membentuk jaring model 3D yang terbentuk dari titik-titik berdekatan yang terhubung satu dengan yang lainnya yang membentuk segitiga maupun tetrahedron [17].

\section{Digital Surface Model (DSM)}

DSM merepresentasikan permukaan model dengan berbagai ketinggian dipermukaan bumi yang mencakup, ground, vegetasi hingga objek buatan manusia.

\section{Mosaik Ortofoto}

Mosaik ortofoto atau orthomosaic adalah gabungan ortofoto atau atau foto udara yang telah tegak, ortogonal, dan terbebas dari kesalahan relief. Umumnya mosaik ortofoto sudah dilengkapi dengan informasi koordinat lokasi sebenarnya di permukaan bumi.

\subsection{Interpretasi Citra}

Interpretasi citra adalah teknik menganalisis obyek pada citra berdasarkan unsur-unsur inetrpretasi, yang antara lain terdiri atas: warna, ukuran, bentuk, pola, tekstur, dan bayangan yang dipadukan dengan konteks visual dan pengalaman surveyor. Oleh karena itu, terdapat faktor non-spasial lainnya yang dapat mempengaruhi interpretasi dalam hal pengenalan visual objek. Umumnya foto udara yang dipotret dengan ketinggian rendah memberikan peringkat interpretabilitas yang jauh lebih tinggi daripada foto udara standar atau citra satelit resolusi tinggi [18]. 


\subsection{Uji Akurasi Tematik}

Uji akurasi tematik adalah tahapan yang dilakukan untuk memverifikasi seberapa akurat hasil interpretasi dan klasifikasi dari citra atau foto udara. Metode yang digunakan untuk menghitung akurasi klasifikasi dengan menggunakan matriks kesalahan atau confusion matrix. Menurut [18], pada tahap uji akurasi tematik perlu dilakukan perhitungan producer accuracy, user accuracy, dan overall accuracy.

\subsection{Lokasi}

Lokasi penelitian ini adalah ruas jalan Jembangan yang berada di Kecamatan Tulung Kabupaten Klaten. Ruas jalan yang diteliti adalah sepanjang 20 meter. Jalan Jembangan merupakan ruas jalan dengan material penyusun aspal serta memiliki lebar badan jalan 4 meter (Gambar 2).

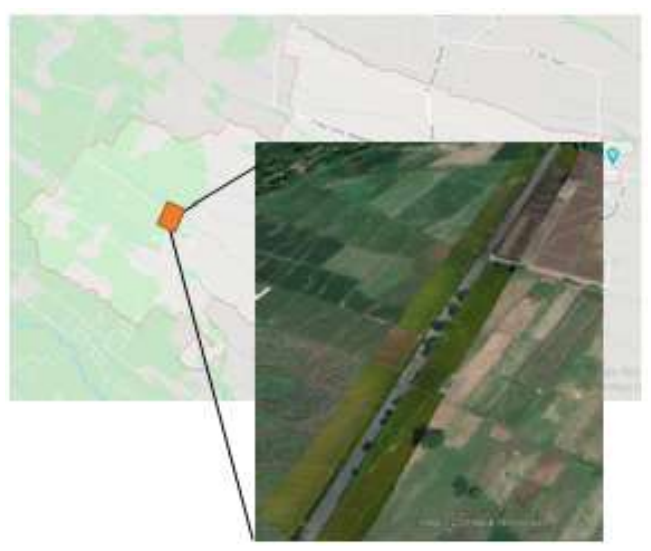

Gambar 2. Lokasi Penelitian

\section{METODE PENELITIAN}

\subsection{Bahan dan Alat}

Perangkat yang digunakan dalam penelitian ini terdiri atas perangkat keras dan perangkat lunak. Perangkat keras yang digunakan untuk pengolahan data adalah Laptop. Perangkat lunak yang digunakan untuk pengolahan data antara lain DJI Go dan perangkat lunak SfM. Peralatan yang digunakan untuk proses akuisisi foto udara berupa satu unit Drone merk DJI Phantom 4 (Gambar 3).

\subsection{Cara Penelitian}

\subsubsection{Akuisisi Data}

Akusisi foto udara dilakukan sepanjang 100 meter selanjutnya akan dilakukan pemotongan pada area of interest kerusakan jalan yang akan diteliti. Akuisisi foto udara menggunakan UAV model quadcopter merk DJI Phantom 4 dengan menggunakan aplikasi Drone Deploy pada smartphone. Ketinggian terbang drone tidak lebih dari 20 meter serta masih memerlukan kontrol oleh pilot dengan petimbangan kemungkinan adanya hambatan oleh objek di sekitar jalan yang tingginya kurang dari 20 meter. Tahapan lengkap penelitian dapat dilihat pada Gambar 4.

Sebelum akuisisi data, terlebih dahulu dilakukan penilaian kondisi lapangan seperti survei awal, identifikasi objek pada sisi jalan yang berpotensi berbahaya serta kondisi cuaca [19]. Kondisi kendaraan di lokasi penelitian juga sangat mempengaruhi hasil foto udara saat misi pemotretan sedang berlangsung. Untuk menghindari efek bayangan awan, pada penelitian ini dilakukan akuisisi foto udara pada pagi hari atau pada jam 08.00-11.00 waktu setempat. Sebelum pemotretan, terlebih dahulu dilakukan pemasangan premark untuk keperluan pengukuran titik kontrol tanah (GCP) pada sisi kiri dan kanan jalan.

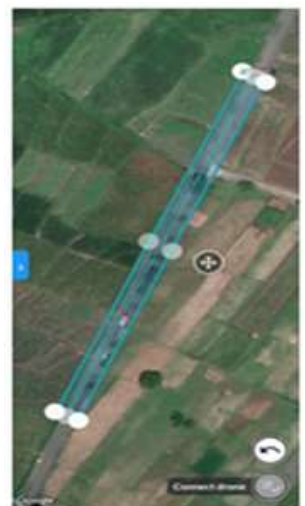

(a)

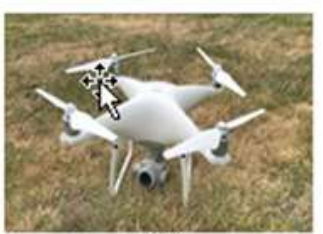

(b)

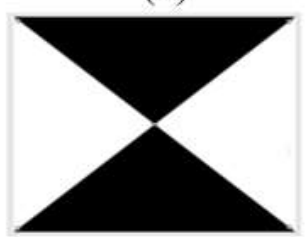

(c)
Gambar 3. (a) Interface Flight Plan pada Drone Deploy, (b) DJI Phantom 4 pro, (c) Premark GCP

\subsubsection{Pengolahan Data}

Tahap pertama pengolahan data foto udara pada perangkat lunak SfM adalah align photo yang bertujuan untuk menemukan posisi dan orientasi kamera pada setiap foto dan membuat sparse cloud model. Pada tahap ini ada 2 aktivitas yakni Feature Detecting dan Feature matching yang secara otomatis menemukan dan mencocokkan sejumlah fitur antara gambar atau yang lebih dikenal dengan algoritma SIFT (Scale Invariant Feature Transform) yang kemudian digunakan sebagai awal untuk menghitung parameter IO dan EO. 
Proses pembentukan dense cloud dibentuk dari sekumpulan titik dengan jumlah ribuan hingga jutaan yang menghasilkan model 3D. Setelah dibentuk dense cloud, langkah selanjutnya adalah membentuk Mesh TIN (triangulated irregular network). Jaring mesh dibentuk dari penarikan garis pada titik-titik dense cloud, sehingga bentuk geometrik 3D objek sudah terbentuk oleh jaring segitiga atau TIN. Pembentukan tekstur merupakan tahap akhir dalam pembentukan model 3D ini. Proses ini merupakan pemberian tekstur objek sesuai foto asli. Pembentukan DSM final dapat dirasterisasi berdasarkan data dense point cloud.

Ortofoto atau mosaik ortofoto adalah gabungan ortofoto yang posisinya sudah sesuai dengan keadaan sebenarnya di permukaan bumi. Mosaik ortofoto selanjutnya digunakan untuk melakukan interpretasi setiap objek yang ada pada foto udara serta memungkinkan untuk melakukan pengukuran geometrik, misal jarak dan luas.

Tahapan klasifikasi jenis jenis kerusakan jalan dilakukan dengan menggunakan teknik interpretasi visual. Interpretasi pada citra merupakan metode untuk memperoleh informasi tentang objek berdasarkan identifikasi dan interpretasi pada objek yang terdapat dalam foto udara atau mosaik ortofoto. Interpretasi yang dimaksud adalah menerjemahkan konten yang beragam berdasarkan persepsi user [20]. Karakteristik setiap objek secara kualitatif maupun posisi objek (spasial) akan menjadi dasar untuk menentukan atribut pada objek yang diteliti.

Hasil klasifikasi selanjutnya adalah pengujian akurasi yang dilakukan terhadap citra hasil interpretasi dengan matriks kesalahan. Hal ini dilakukan dengan membandingkan citra hasil klasifikasi terhadap kelas atau objek sebenarnya yang diperoleh berdasarkan pengamatan di lapangan.

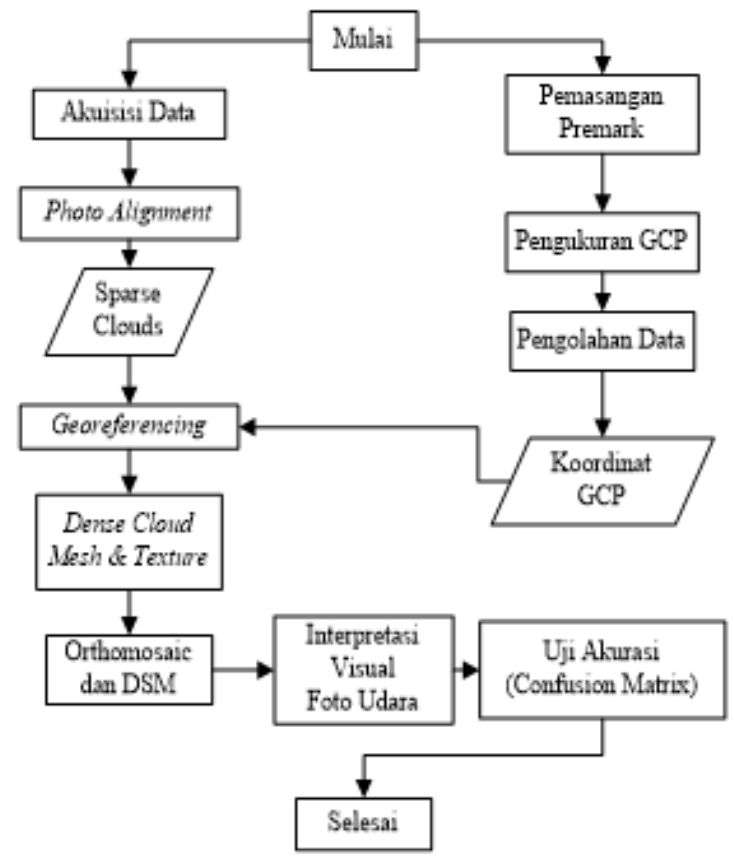

Gambar 4. Diagram Alir Pelaksanaan

\section{HASIL DAN PEMBAHASAN}

\subsection{Akuisisi Data}

Tahapan akuisisi data menggunakan aplikasi bantu pada smartphone yakni Drone Deploy yang berfungsi untuk pembuatan jalur terbang serta pengaturan overlap dan sidelap, kecepatan wahana, durasi terbang, ketika wahana diterbangkan secara otomatis. Perencanaan jalur terbang dan contoh foto udara yang dihasilkan dapat dilihat pada Gambar 5 dan Gambar 6.

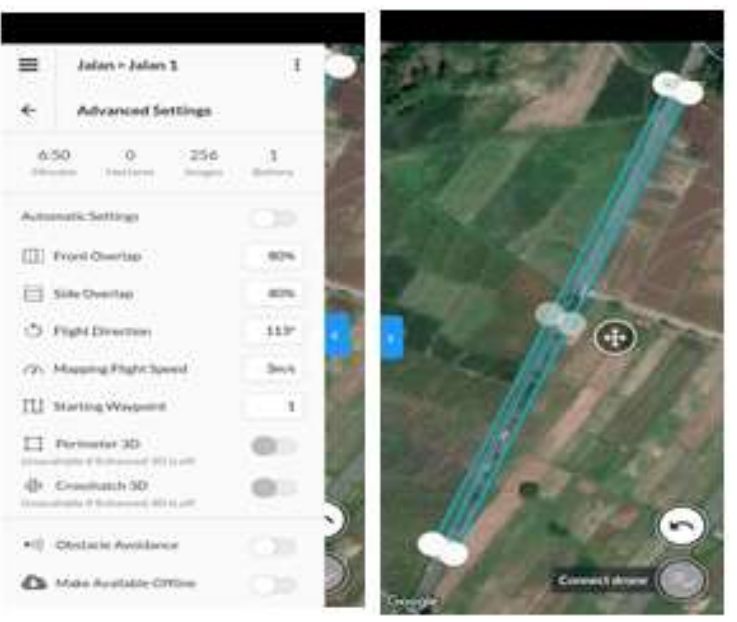

Gambar 5. Perencanaan Jalur Terbang Pada Drone Deploy 
Pada penelitian ini, UAV terbang pada ketinggian kurang dari $20 \mathrm{~m}$ dengan sidelap dan frontlap masing-masing sebesar $80 \%$ dengan kecepatan terbang $3 \mathrm{~m} / \mathrm{s}$. Untuk cakupan area disesuaikan dengan panjang ruas jalan yang diteliti serta durasi terbang baterei DJI Phantom 4. Lama waktu akuisisi data yakni 6 menit 50 detik yang menghasilkan total 256 foto, salah satunya seperti ditampilkan pada Gambar 6.

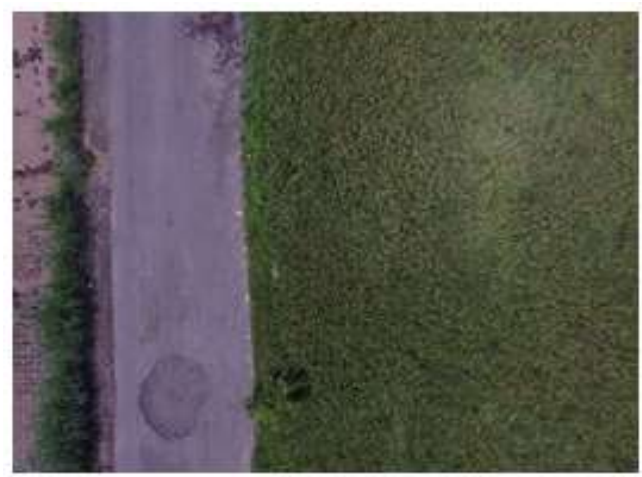

Gambar 6. Contoh Foto Hasil Pemotretan Udara

\subsection{Pengolahan Data Foto}

Foto-foto tersebut selanjutnya diproses dengan menggunakan software SfM. Tahap pertama dalam pemrosesan foto udara yakni melakukan align photo.

Di dalam tahapan align photo, terjadi proses feature detection dan feature Description. Proses identifikasi fitur dilakukan dengan menggunakan tehnik image matching. Algoritma ini merupakan salah satu pendekatan dalam computer vision yang mencari serta menemukan fitur yang khas pada serangkaian foto. Salah satu algoritma image matching yang digunakan dalam adalah algortima SIFT.

Dari hasil tahapan align photo diperoleh 78617 tie point dari hasil alignment sebanyak 256 foto udara pada 3 strip jalur terbang. Tie point ini merupakan hasil identitifkasi setiap fitur yang khas pada setiap foto yang juga terdapat pada foto lain. Jumlah titik titik matching berjumlah ratusan hingga ribuan tergantung pada tingkat akurasi saat melakukan align photo. Di samping itu, terdapat total 1226 matching point yang tidak valid. Hal ini disebakan karena sulitnya mengenali fitur yang khas pada vegetasi (rumput dan semak belukar) yang berada pada sisi jalan.

Selain untuk memperoleh IO, tahapan align photo juga menghasilkan EOP. Penelitian ini menggunakan metode self callibration untuk memperoleh parameter IO. Kamera quadcopter DJI Phantom 4 memiliki ukuran piksel $1,56 \mu \mathrm{m} \times 1,56 \mu \mathrm{m}$ dengan tipe kamera frame serta focal length sebesar 3,61 mm. Dari hasil kalibrasi kamera diperoleh grafik distorsi yang memiliki kesalahan sebesar 0,788 piksel seperti Gambar 7.

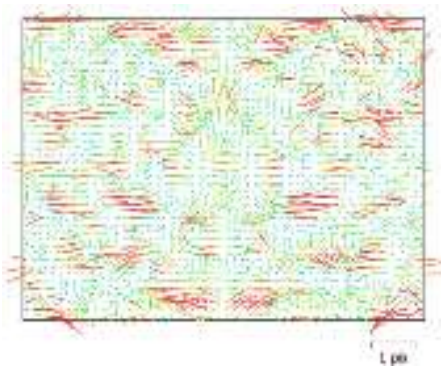

Gambar 7. Grafik Residual Hasil Kalibrasi Kamera Dengan Metode Self Calibration

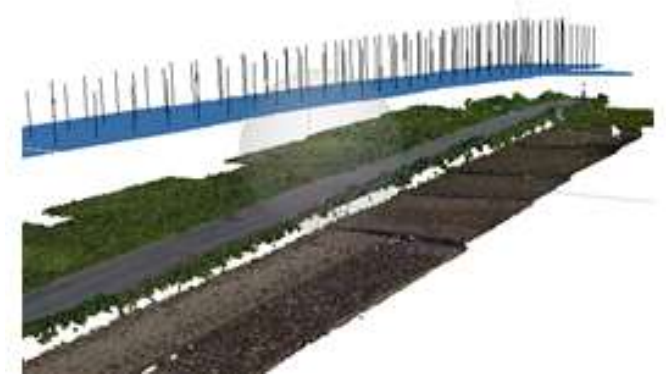

Gambar 8. Posisi Kamera Saat Melakukan Pemotretan

Pada hasil pemrosesan Dense point cloud menghasilkan point cloud yang sangat padat dengan estimasi 2.025 .408 point serta durasi pemrosesan selama 37 menit dari 60 gambar UAV pada ketinggian $18 \mathrm{~m}$. Point cloud yang dihasilkan dari tahapan align photo adalah sekumpulan titik yang dinyatakan dalam sistem koordinat 3D. Kumpulan titik Point cloud yang sangat rapat memiliki koordinat $\mathrm{X}, \mathrm{Y}$ dan $\mathrm{Z}$ yang mewakili permukaan suatu objek. Data point cloud merupakan data yang sangat penting karena digunakan untuk membuat model 3D suatu area. Proses pembuatan model 3D adalah dengan menggunakan metode surface reconstruction pada permukaan objek dengan cara memanipulasi polygon, edge dan node sehingga menghasilkan mesh model 3D. Selanjutnya adalah tahap texturing untuk membuat model nampak seperti foto realistik (Gambar 9). 


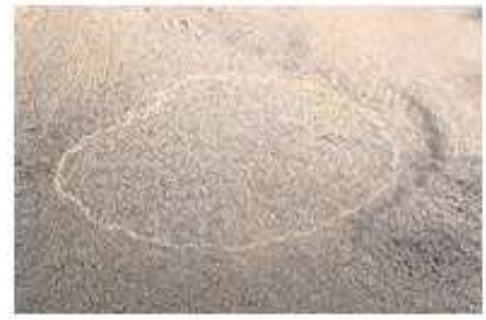

(a) Dense Cloud

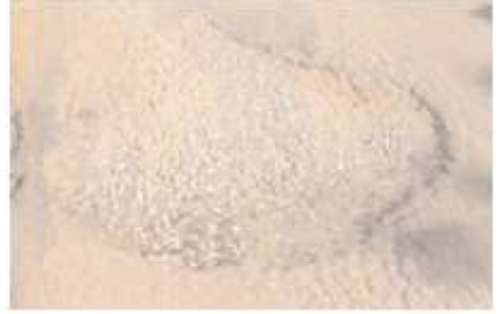

(b) Texture

Gambar 9. Dense Cloud dan Pembentukan Tekstur Pada Foto Udara

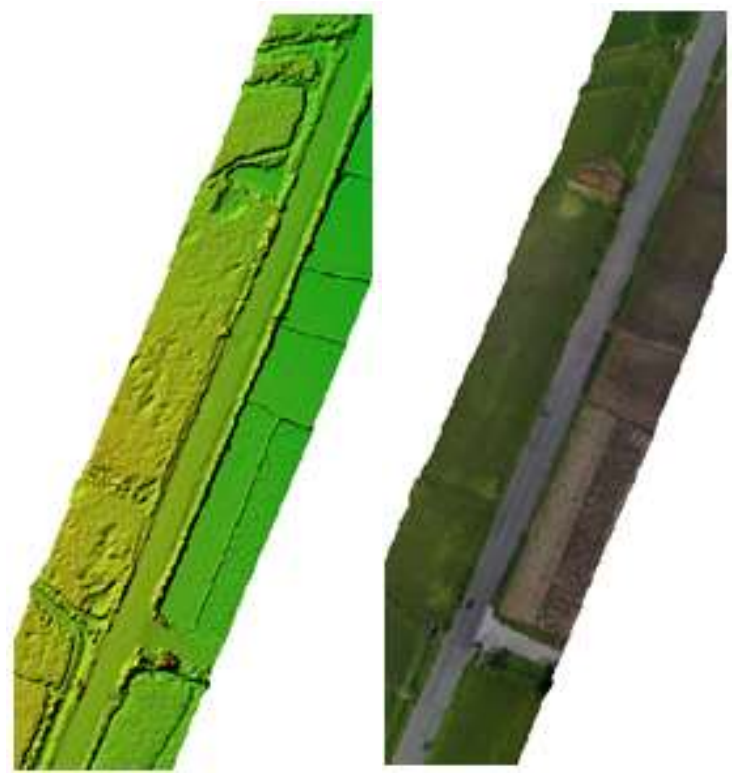

Gambar 10. Visualisasi DSM (kiri) dan Mosaik Ortofoto (kanan)

Tahapan selanjutnya adalah membuat DSM serta mosaik ortofoto. DSM dianalisis dari parameter dense points cloud yang diinterpolasi. Adapun mosaik ortofoto dibentuk untuk menghasilkan citra piktorial 2D yang teliti dan realistik. Keseluruhan mosaik ortofoto yang dihasilkan masih mencakup area sawah yang berada di sisi kiri dan kanan jalan. Sesuai dengan tujuan penelitian ini yang berfokus untuk identifikasi dan klasifikasi kerusakan jalan, sehingga dilakukan pemotongan citra yang hanya mencakup permukaan aspal, sebagaimana disajikan pada Gambar 10.

\subsection{Interpretasi Visual}

Klasifikasi setiap jenis-jenis kerusakan jalan didasarkan pada kelompok piksel yang dideteksi dan diidentifikasi mempunyai kesamaan/kemiripan warna, tekstur, dan rona. Setiap Jenis kerusakan yang diidentifikasi terdiri atas piksel-piksel yang relatif homogen atau dengan berbagai tingkat variasi objek. Penentuan kelas kerusakan pada kelompok piksel yang bervariasi dilakukan berdasarkan warna dan rona dominan yang mendominasi area tersebut.

Dari segi pola, kerusakan alligator cracking terusun atas serangkaian retak memanjang paralel yang membentuk banyak sisi menyerupai kulit buaya. Kerusakan amblas berupa penurunan pada lapisan tanah dasar yang diikuti lapisan permukaan. Lubang memiliki karakteristik berbentuk seperti mangkuk yang terbentuk sebagai akibat dari retakan yang tidak dirawat yang semakin lama semakin meluas akibat genangan air. Lubang (potholes) memiliki kedalaman $>25 \mathrm{~mm}$ dengan diameter $0,9 \mathrm{~m}$ atau lebih. Sungkur (shoving) berupa perpindahan lapisan perkerasan yang menghasilkan pola kerusakan seperti ombak pada permukaan aspal. Retak tepi (edge cracking) terdiri dari retak retak memanjang tanpa cabang yang terletak pada bahu jalan. Adapun kerusakan tambalan (patch) berupa bekas tambalan jalan yang berbentuk segi empat (pola tambalan) sebelumnya yang telah mengalami kerusakan.

Dari aspek warna atau rona, terlihat bahwa tidak ada warna yang cukup kontras yang membedakan setiap jenis kerusakan. Hal ini disebabkan bahwa jenis kerusakan memiliki warna yang menyerupai warna perkerasan jalan aspal yakni warna abu abu hingga hitam. Pada kerusakan shoving, material halus lapisan pondasi yang berwarna kecokelatan sedangkan untuk jenis kerusakan amblas, terdapat genangan air yang berwarna cokelat pekat. Pada jenis kerusakan lubang, penilaian visual didasarkan terhadap tepi kerusakan yang terlihat jelas seperti Gambar 11. 

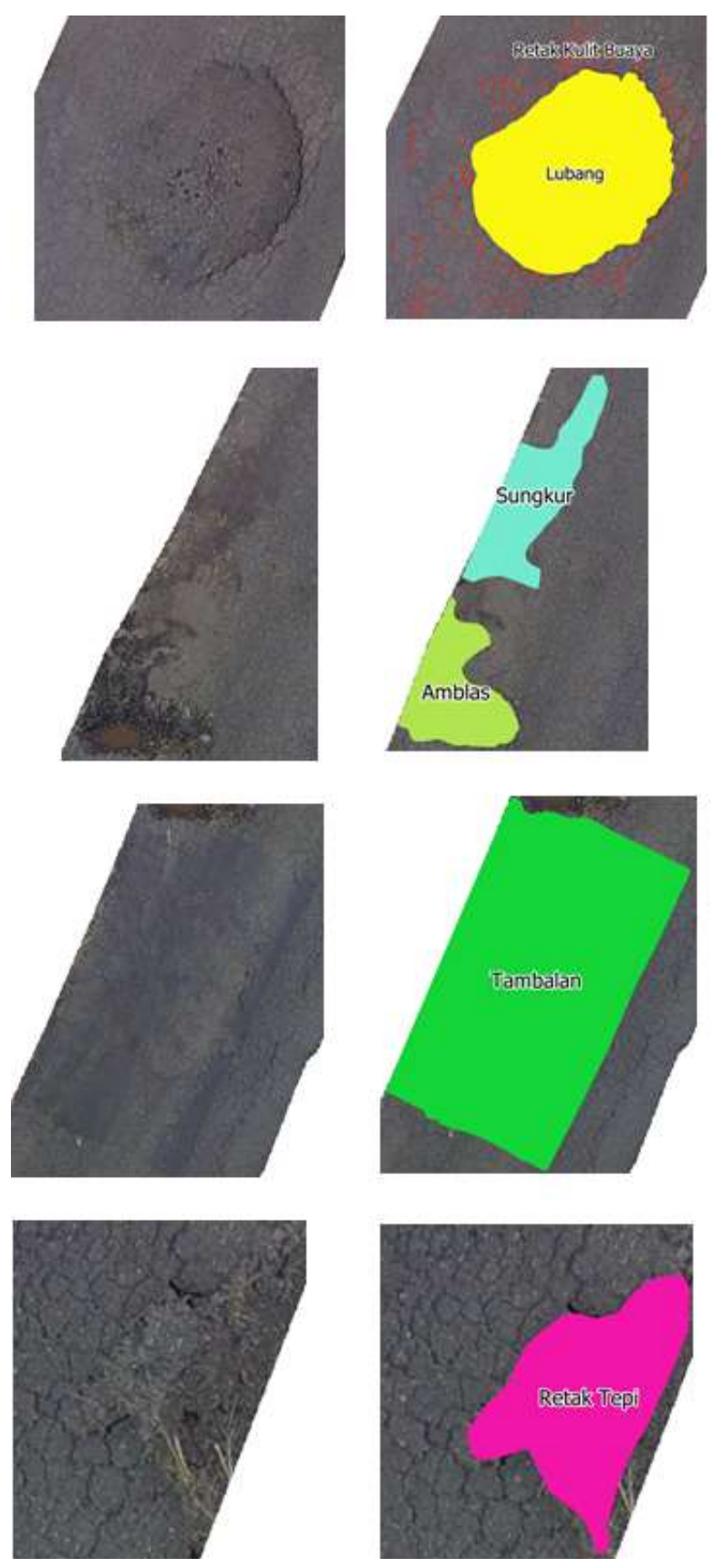

Gambar 11. Hasil Interpretasi Visual Jenis-jenis Kerusakan Jalan

Jenis jenis kerusakan jalan yang dapat diidentifikasi berdasarkan interpretasi visual adalah kerusakan lubang (potholes), sungkur (shoving), amblas (depression), retak kulit buaya (alligator cracking), tambalan (patch) dan retak tepi (edge cracking).

Selanjutnya dilakukan analisis terhadap luasan masing-masing jenis kerusakan jalan dengan menggunakan analisis spasial. Tabel 1 menunjukan luasan jenis jenis kerusakan jalan yang diklasifikasi berdasarkan interpretasi visual.
Tabel 1. Luasan Tiap Jenis Kerusakan Jalan

\begin{tabular}{c|l|c}
\hline No & Keterangan & Luas $\left(\mathrm{m}^{2}\right)$ \\
\hline 1 & Retak Kulit Buaya & 0,40 \\
\hline 3 & Lubang & 4,64 \\
\hline 4 & Tambalan & 18,58 \\
\hline 4 & Amblas & 2,34 \\
\hline 5 & Sungkur & 2,67 \\
\hline 6 & Retak Tepi & 0,44 \\
\hline
\end{tabular}

\subsection{Uji Akurasi}

Setelah klasifikasi terhadap jenis jenis kerusakan jalan dilakukan, langkah selanjutnya adalah melakukan penilaian akurasi untuk memeriksa kualitas hasil klasifikasi tiap jenis kerusakan jalan. Lokasi referensi untuk setiap kelas kerusakan jalan dikumpulkan menggunakan interpretasi visual terhadap mosaik ortofoto. Titik-titik referensi tersebut ditempatkan secara acak dengan menggunakan metode stratified random sampling dalam setiap kelas dengan jumlah yang proporsional tergantung pada area yang dianalisis.

Penentuan tingkat akurasi klasifikasi dinilai berdasarkan akurasi produser (producer accuracy), akurasi user (user accuracy), akurasi total (overall accuracy), dan nilai Kappa. Producer accuracy menunjukkan persentase setiap objek di lapangan yang diklasifikasikan dengan benar, sedangkan user accuracy menunjukkan persentase hasil klasifikasi yang secara aktual sesuai atau mewakili kondisi di lapangan.

Overall accuracy merupakan persentase yang menggambarkan nilai akurasi total hasil klasifikasi. Nilai Kappa selain ditentukan oleh objek yang diklasifikasikan dengan benar juga memperhitungkan kesalahan klasifikasi[21].

Tabel 2 menunjukkan confusion matrix pada hasil klasifikasi kerusakan jalan Jembangan, diperoleh overall accuracy sebesar $96,36 \%$. Nilai ini menunjukkan bahwa kesalahan klasifikasi adalah 3,64\%. Kesalahan ini disebabkan ada beberapa area yang diklasifikasi pada kelas yang salah untuk jenis kerusakan sungkur (shoving) dan amblas (depression). Hasil klasifikasi menunjukkan nilai Kappa sebesar 94,15 \% hal ini menunjukkan tingkat kepercayaan terhadap hasil klasifikasi tergolong dalam kategori tinggi. 
Tabel 2. Hasil Uji Akurasi Terhadap Hasil Klasifikasi Interpretasi Visual

\begin{tabular}{|c|c|c|c|c|c|c|c|c|}
\hline $\begin{array}{c}\text { Jenis } \\
\text { Kerusakan } \\
\end{array}$ & $\begin{array}{c}\text { Retak } \\
\text { Tepi }\end{array}$ & Tambalan & Lubang & Amblas & Sungkur & $\begin{array}{c}\text { Retak Kulit } \\
\text { Buaya }\end{array}$ & Total & $\begin{array}{c}\text { User } \\
\text { Accuracy }\end{array}$ \\
\hline Retak Tepi & 10 & 0 & 0 & 0 & 0 & 0 & 10 & $100 \%$ \\
\hline Tambalan & 0 & 95 & 0 & 0 & 0 & 0 & 95 & $100 \%$ \\
\hline Lubang & 0 & 0 & 24 & 0 & 0 & 0 & 24 & $100 \%$ \\
\hline Amblas & 0 & 2 & 0 & 10 & 0 & 0 & 12 & $83 \%$ \\
\hline Sungkur & 0 & 0 & 0 & 0 & 10 & 4 & 14 & $71 \%$ \\
\hline $\begin{array}{c}\text { Retak Kulit } \\
\text { Buaya }\end{array}$ & 0 & 0 & 0 & 0 & 0 & 10 & 10 & $100 \%$ \\
\hline Total & 10 & 97 & 24 & 10 & 10 & 14 & 165 & \\
\hline $\begin{array}{l}\text { Producer } \\
\text { Accuracy }\end{array}$ & $100 \%$ & $97 \%$ & $100 \%$ & $100 \%$ & $100 \%$ & $71 \%$ & & \\
\hline $\begin{array}{c}\text { Overall } \\
\text { Accuracy }\end{array}$ & \multicolumn{8}{|c|}{$96,36 \%$} \\
\hline Kappa & \multicolumn{8}{|c|}{$94,15 \%$} \\
\hline
\end{tabular}

\section{KESIMPULAN}

Jenis-jenis kerusakan jalan pada ruas jalan Jembangan dapat diklasifikasi dengan baik dengan menggunakan metode interpretasi visual pada citra ortofoto yang diperoleh dari hasil pemotretan menggunakan wahana UAV. Pada ruas jalan tersebut dapat diidentifikasi 6 jenis kerusakan, yaitu: jenis kerusakan retak kulit buaya (alligator cracking), sungkur (shoving), amblas (depression), tambalan (patch), retak tepi (edge cracking) dan lubang (potholes). Secara keseluruhan, klasifikasi jenis-jenis kerusakan jalan berdasarkan hasil interpretasi visual menunjukkan akurasi sebesar 96,36\% dan nilai Kappa sebesar 94,15\%.

Hasil analisis terhadap luas setiap kerusakan yang diklasifikasi menunjukkan bahwa jenis kerusakan tambalan (patch) memiliki luas $18,58 \mathrm{~m}^{2}$. Tambalan merupakan jenis kerusakan yang dominan pada ruas jalan yang diteliti. Jenis kerusakan dengan luas terkecil pada area penelitian adalah jenis kerusakan retak tepi (edge cracking) dan retak kulit buaya (alligator cracking). Kedua jenis kerusakan tersebut masing-masing memiliki luas $0,44 \mathrm{~m}^{2}$ dan $0,40 \mathrm{~m}^{2}$.

Berdasarkan hasil penelitian ini dapat dilihat bahwa teknologi UAV dapat diandalkan untuk inspeksi jenis kerusakan jalan pada permukaan perkerasan lentur (aspal). Selain berbiaya rendah, penggunaan UAV juga tergolong lebih fleksibel serta mudah dioperasikan dan menghasilkan citra resolusi tinggi.

\section{DAFTAR PUSTAKA}

[1] T.Fwa, The Handbook of Highway Engineering. Florida, 2006.

[2] M. Uljarevic and S. Supic, "Comparative Analysis of Flexible and Rigid Pavement Design," Contemp. Constr. Achiev. Civ. Eng., pp. 835-844, 2016.

[3] M. Herold and D. Roberts, "Spectral characteristics of asphalt road aging and deterioration: implications for remote-sensing applications," Appl. Opt., vol. 44, no. 20, 2005.

[4] N. Bandara, "Current and Future Pavement Maintenance Prioritization Based on Rapid Visual Condition Evaluation," J. Transp. Eng. March 2001, no. April, pp. 116-123, 2001.

[5] E. Schnebele, "Review of remote sensing methodologies for pavement management and assessment," Eur. Transp. Res. Rev., 2015.

[6] W.Miller, J.S. \& Bellinger, "Distress Identification Manual for the Long-Term Pavement Performance Program," in U.S Department of Transportation Federal Highway Administration, no. May, U.S Department of Transportation Federal Highway Administration, 2014.

[7] J. Everaerts, "The Use of Unmanned Aerial Vehicles (UAVs) for Remote Sensing and Mapping," Int. Arch. Photogramm. Remote Sens. Spat. Inf. Sci. Beijing, vol. XXXVII, pp. 1187-1192, 2008.

[8] N. Arsyad, "Akurasi Citra data Foto Udara Persimpangan Lalu Lintas Kota Kendari," Rekayasa Sipil, vol. 14, no. 1, pp. 51-59, 2020.

[9] J. P. Dash, M. S. Watt, G. D. Pearse, M. Heaphy, and H. S. Dungey, "ISPRS Journal of Photogrammetry and Remote Sensing Assessing 
very high resolution UAV imagery for monitoring forest health during a simulated disease outbreak," ISPRS J. Photogramm. Remote Sens., vol. 131, pp. 1-14, 2017.

[10] S. Valkaniotis, G. Papathanassiou, and A. Ganas, "Mapping an earthquake-induced landslide based on UAV imagery ; case study of the 2015 Okeanos landslide, Lefkada , Greece," Eng. Geol., vol. 245, no. August, pp. 141-152, 2018.

[11] M. Arturo and A. Ndoma, "The Uses of Unmanned Aerial Vehicles - UAV's- (or drones) in Social Logistic : Natural Disasters Responses and Humanitarian Relief Aid," Procedia Comput. Sci., vol. 149, pp. 375-383, 2019.

[12] et al Ragnoli, "Pavement Distress Detection Methods: A Review," Infrastructures, vol. 3, no. 4, p. 58, 2018.

[13] S. Radopoulou, "A Framework for Automated Pavement Condition Monitoring," Constr. Res. Congr., no. Asce 2013, pp. 770-779, 2016.

[14] S. C. Radopoulou and I. Brilakis, "Automation in Construction Patch detection for pavement assessment," Autom. Constr., vol. 53, pp.
95-104, 2015.

[15] T. Luhmann, Close Range Photogrammetry, vol. 30, no. 151. 2011.

[16] M. J. Westoby, “'Structure-from-Motion' photogrammetry: A low-cost, effective tool for geoscience applications," Geomorphology, vol. 179, pp. 300-314, 2012.

[17] C. Zhang and T. Chen, "Efficient Feature Extraction for 2D/3D Objects In Mesh Representation," Virtual Real., pp. 1-4, 2001.

[18] J. Aber, I. Marzolff, and J. Ries, Small-Format Aerial Photography, First., vol. 25, no. 11. 2010.

[19] M. Prajwal, "Optimal Number of Ground Control Points for a UAV based Corridor Mapping," Int. J. Innov. Res. Sci. Eng. Technol., vol. 5, no. 9, pp. 28-32, 2016.

[20] H. Svatonova, "Analysis of visual interpretation of satellite data," Int. Arch. Photogramm. Remote Sens. Spat. Inf. Sci. - ISPRS Arch., vol. 41, no. July, pp. 675-681, 2016.

[21] R. G. Congalton, "Accuracy Assessment and Validation of Remotely Sensed and Other Spatial Information," Int. J. Wildl. Fire, 2001. 